\title{
HLA-G: A Versatile Biomarker
}

\author{
Mugdha Vasireddi*
}

National B Virus Resource Centre, Viral Immunology Centre, Georgia State University, Atlanta 30303, USA

${ }^{*}$ Corresponding author: Mugdha Vasireddi, Research Scientist and Clinical Laboratory Director, National B Virus Resource Centre, Viral Immunology Centre, Georgia State University, Atlanta 30303, USA, Tel: 404-413-6565; E-mail: mvasireddi1@gsu.edu

Received date: Feb 04, 2017; Accepted date: Feb 17, 2017; Published date: Feb 27, 2017

Copyright: (c) 2017 Vasireddi M. This is an open-access article distributed under the terms of the Creative Commons Attribution License, which permits unrestricted use, distribution, and reproduction in any medium, provided the original author and source are credited.

Citation: Vasireddi M, HLA-G: A Versatile Biomarker. Biomarkers J. 2017, 3:1.

\section{Abstract}

HLA-G is a non-classical MHC Class I molecule that is usually restricted to cytotrophoblasts and other fetal cells in order to protect the fetus from maternal immune responses. However, HLA-G is expressed during viral infections and cancer. The presence of soluble HLA-G, sHLA-G, in serum is noted in various instances of human diseases. Serum HLA-G can serve as a biomarker, which makes it a unique tool in developing confirmatory diagnostics for infectious diseases and cancer. An accurate and early diagnosis of deadly diseases is really important for an early intervention or treatment. The immunosuppressive capabilities of HLA-G make it not only a biomarker for diagnosis but also an excellent target for developing therapeutics. Here, I discuss HLA-G's potential to be an invaluable tool as a biomarker for diagnostics and a target for therapeutics.

\section{HLA-G}

Major histocompatibility class I or MHC class I can be divided into two categories: classical and non-classical $\mathrm{MHC}$ class I. The classical MHC class I consists of HLA-A, $-B$, and $-C$ proteins, while HLA-E and HLA-G are considered non-classical $\mathrm{MHC}$ class I proteins. HLA-A, $-\mathrm{B}$, and $-\mathrm{C}$ present foreign antigen to $\mathrm{CD} 8+$ T-cells and result in subsequent cytotoxicity of infected cells. Thus, the classical HLA-A, $-B$, and $-C$ are mostly involved in immune responsive pathways; however, HLA-G in contrast is an immunosuppressive protein. HLA-G exists in 7 isoforms (HLA-G1- HLA-G7) as a result of alternative splicing [1]. Of these 7 isoforms, membrane bound HLA-G1 and soluble HLA-G5 is well studied and implicated in immune suppression.

HLA-G induces tolerogenic properties in immune cells of both innate and adaptive immune systems. HLA-G binds to the inhibitory receptors such as ILT-2, ILT-4, KIR2DL4 present on the surface of APCs, NK cells, T-cells and B-cells [2]. ILT2 and ILT4 bind preferentially to HLA-G molecules compared to the classical MHC class I molecules [3]. ILT2 inhibitory receptors are expressed on APCs, NK cells, T- and B- cells, whereas ILT4 was found to be expressed mostly on myeloid APCs. It has also been shown that HLA-G binding to ILT4 of myeloid APCs results in inhibition of APC maturation and converting these cells to regulatory tolerogenic cells incapable to activating T-cells $[4,5]$.

HLA-G exhibits a unique characteristic of incorporating itself into another cell such as NK cell [6] and T-cell [7]. This process is called trogocytosis, where membrane proteins or membrane patches from one cell incorporate themselves to another upon contact. Trogocytosis of HLA-G to NK or T-cell results in inhibition of their activation [8]. The expression of HLA-G results in long term immune suppression via many different ways, thus making HLA-G a very unique MHC class I protein capable of causing not only a localized, but also a global immune suppression when expressed.

SHLA-G is not only detected in pregnant women but also detected during infectious diseases such as hCMV [9], hepatitis $[10,11]$, and HIV [12] infections. HLA-G was reported to be expressed on cells infected with rabies virus $[13,14]$, influenza virus [15], and herpes B virus [16]. In our lab, we have shown that herpes $B$ virus infected human cells induce increased surface expression of HLA-G but HSV-1 infected cells do not show similar HLA-G expression [16]. Preliminary results from our lab also suggested that individuals that are positive for herpes B virus infection but not HSV expressed SHLA-G in their serum (unpublished data). Collectively, these data indicate that serum HLA-G can be an important biomarker in differentiating between HSV-1 and herpes B virus infections in humans. Although HLA-G can be induced during other infectious diseases, it serves as a biomarker for developing confirmatory diagnostics.

Confirmatory diagnosis is especially important in case of early detection of cancer for an appropriate and effective treatment. Expression of sHLA-G was reported in patients with ovarian cancer [17], cervical cancer due to human papilloma virus [18], melanoma [19], and gastric cancer [20] etc. Detailed studies on the expression of HLA-G in relation to the stage of cancer progression can help in developing diagnostic tools for early cancer detection and cancer staging. Early detection of cancer is an invaluable tool in preventing cancer metastasis.

Because of the immunosuppressive nature of HLA-G, the expression of HLA-G can be altered to prevent immune suppression and promote robust immune responses to fight many human diseases making it a potential target for 
developing therapeutics. Due to immunosuppressive capability of HLA-G, it can also be induced to suppress an unusually active immune system such as in the case multiple sclerosis, an autoimmune disease. Thus, HLA-G functions as an extremely versatile protein in developing accurate diagnostics and effective therapeutics.

\section{References}

1. Ishitani A, Geraghty DE (1992) Alternative splicing of HLA-G transcripts yields proteins with primary structures resembling both class I and class II antigens. Proc Natl Acad Sci USA 89: 3947-3951.

2. LeMaoult J, Zafaranloo K, Le Danff C, Carosella ED (2005) HLA-G up-regulates ILT2, ILT3, ILT4, and KIR2DL4 in antigen presenting cells, NK cells, and T cells. FASEB J 19: 662-664.

3. Shiroishi M, Tsumoto $K$, Amano K, Shirakihara $Y$, Colonna $M$, et al. (2003) Human inhibitory receptors Ig-like transcript 2 (ILT2) and ILT4 compete with CD8 for MHC class I binding and bind preferentially to HLA-G. Proc Natl Acad Sci USA 100: 8856-8861.

4. Ristich V, Liang S, Zhang W, Wu J, Horuzsko A (2005) Tolerization of dendritic cells by HLA-G. Eur J Immunol 35: 1133-1142.

5. Liang S, Horuzsko A (2003) Mobilizing dendritic cells for tolerance by engagement of immune inhibitory receptors for HLA-G. Hum Immunol 64: 1025-1032.

6. Caumartin J, Favier B, Daouya M, Guillard C, Moreau P, et al. (2007) Trogocytosis-based generation of suppressive NK cells. EMBO J 26: 1423-1433.

7. Brown R, Kabani K, Favaloro J, Yang S, Ho PJ, et al. (2012) CD86+ or HLA-G+ can be transferred via trogocytosis from myeloma cells to $T$ cells and are associated with poor prognosis. Blood 120: 2055-2063.

8. LeMaoult J, Caumartin J, Carosella ED (2007) Exchanges of membrane patches (trogocytosis) split theoretical and actual functions of immune cells. Hum Immunol 68: 240-243.

9. Onno M, Pangault C, Le Friec G, Guilloux V, Andre P, et al. (2000) Modulation of HLA-G antigens expression by human cytomegalovirus: specific induction in activated macrophages harboring human cytomegalovirus infection. J Immunol 164: 6426-6434.

10. Weng PJ, Fu YM, Ding SX, Xu DP, Lin A, et al. (2011) Elevation of plasma soluble human leukocyte antigen- $G$ in patients with chronic hepatitis C virus infection. Hum Immunol 72: 406-411.
11. Shi WW, Lin A, Xu DP, Bao WG, Zhang JG, et al. (2011) Plasma soluble human leukocyte antigen- $G$ expression is a potential clinical biomarker in patients with hepatitis $B$ virus infection. Hum Immunol 72: 1068-1073.

12. Murdaca G, Contini P, Setti M, Cagnati P, Lantieri F, et al. (2009) Behavior of non-classical soluble HLA class $G$ antigens in human immunodeficiency virus 1 -infected patients before and after HAART: comparison with classical soluble HLA-A, $-B,-C$ antigens and potential role in immune-reconstitution. Clin Immunol 133: 238-244.

13. Lafon M, Prehaud C, Megret F, Lafage M, Mouillot G, et al. (2005) Modulation of HLA-G expression in human neural cells after neurotropic viral infections. J Virol 79: 15226-15237.

14. Megret F, Prehaud $C$, Lafage $M$, Moreau P, Rouas-Freiss $N$, et al. (2007) Modulation of HLA-G and HLA-E expression in human neuronal cells after rabies virus or herpes virus simplex type 1 infections. Hum Immunol 68: 294-302.

15. LeBouder F, Khoufache K, Menier C, Mandouri Y, Keffous M, et al. (2009) Immunosuppressive HLA-G molecule is upregulated in alveolar epithelial cells after influenza A virus infection. Hum Immunol 70: 1016-1019.

16. Vasireddi M, Hilliard J (2012) Herpes B virus, macacine herpesvirus 1 , breaks simplex virus tradition via major histocompatibility complex class I expression in cells from human and macaque hosts. J Virol 86: 12503-12511.

17. Sheu JJ, Shih le M (2007) Clinical and biological significance of HLA-G expression in ovarian cancer. Semin Cancer Biol 17: 436-443.

18. Guimaraes MC, Soares CP, Donadi EA, Derchain SF, Andrade LA, et al. (2010) Low expression of human histocompatibility soluble leukocyte antigen-G (HLA-G5) in invasive cervical cancer with and without metastasis, associated with papilloma virus (HPV). J Histochem Cytochem 58: 405-411.

19. Paul P, Rouas-Freiss N, Khalil-Daher I, Moreau P, Riteau B, et al. (1998) HLA-G expression in melanoma: a way for tumor cells to escape from immunosurveillance. Proc Natl Acad Sci USA95: 4510-4515.

20. Ishigami S, Natsugoe S, Miyazono F, Nakajo A, Tokuda K, et al. (2006) HLA-G expression in gastric cancer. Anticancer Res 26: 2467-2472. 